\title{
Molecular Characterization of Bacterial Phylogenetic and Functional Groups at Terrebonne Bay along the Coastline of the Gulf of Mexico Ola A Olapade*
}

Department of Biology and the Center for Sustainability and the Environment, Albion College, 611 East Porter Street, Albion, MI 49224, USA

\begin{abstract}
The detection and quantification of bacterial phylogenetic and functional groups as well as community diversity at the site of the Deepwater Horizon oil spill in Terrebonne Bay along the Gulf of Mexico were carried out using nucleic acid staining, Fluorescence in situ Hybridization (FISH) and 16S rRNA gene cloning and sequencing approaches. Results from the $16 \mathrm{~S}$ rRNA gene clone library analysis revealed high occurrences of bacterial members belonging to the Cyanobacteria (28\%), $\beta$-Proteobacteria (21\%), Bacteroidetes (17\%), Actinobacteria $(12 \%)$ and the $\alpha$-Proteobacteria (10\%). Particularly, bacterial members identified within the clone library as belonging to the $\beta$-Proteobacteria subclass were mostly hydrocarbon degraders, including Methylibium petroleiphilum, Burkholderia cepacia, Hydrogenophaga taeniospiralis and Methylobacillus flagellates. Simultaneous analyses of both planktonic and benthic bacterial communities by FISH revealed the numerical dominance of members of the type I Methanotrophic Bacteria (MB) over the type II populations. The results from the study clearly reveal a shift in the bacterial community structure and composition in response to the tragic methane and crude oil discharges from the Deepwater Horizon rig along the Gulf of Mexico.
\end{abstract}

Keywords: 16S rRNA gene; Fluorescence in situ hybridization; Pollution; Coastal marine

\section{Introduction}

The diversity and global distributions of bacterial populations within indigenous microbial assemblages in marine environments have been well documented because of their significant ecological importance within various milieus [1-8]. For instance, there is currently ample and incontrovertible evidence that bacterial assemblages within coastal marine milieus do not only rapidly respond to oil spills, but also contribute their wide arrays of hydrocarbon degrading capabilities to the effective bioremediation of oil residues in contaminated environments [9-11]. Given the presence of diverse degradative genes needed for in situ clean up of complex hydrocarbon pollutants, accurate delineation of in situ microbial assemblages is therefore paramount in order to effectively understand the overall dynamics of microbial response and biodegradation process in oil polluted sites. Even more so that it is common knowledge that microbial assemblages are influenced by various controlling factors, including pollutant type and bioavailability, nutrient dynamics as well as continuous fluxes in site-specific hydrodynamic conditions within marine environments [12-15].

This study elucidated in situ microbial compositions in response to the tragic crude oil and methane discharges that resulted due to the severance of the Deep water Horizon rig from its well offshore on the Gulf of Mexico (GOM) in 2010. This tragic pollution event ultimately released approximately $1.3 \times 10^{10}$ moles of methane and 205 million gallons (i.e.780,000 $\mathrm{m}^{3}$ ) of crude oil into surrounding environments of affected GOM sites [14]. Shortly after the incidence, the widespread dispersal of hydrocarbon plume was linked to the stimulation of indigenous bacterial populations, especially the $\gamma$ - Proteobacteria members known to be closely associated with petroleum degradation $[15,16]$. Furthermore, these studies also found strong correlations between the occurrences of several hydrocarbon-degrading genes and various components of the hydrocarbon plume at the GOM sites examined.
Therefore, combinations of $16 \mathrm{~S}$ ribosomal RNA gene sequencing, nucleic acid staining and fluorescence in situ hybridization (FISH) analyses were employed to qualitatively and quantitatively examine the phylogenetic composition and community diversity within the bacterioplankton assemblages at one of the most contaminated coastal location along the Gulf of Mexico. Quantitative analysis by FISH was particularly employed to target bacterial phyla with hydrocarbon-utilizing capabilities, including two subclasses (i.e. aand $\gamma-$ ) of Proteobacteria and members of the methanotrophs (i.e. type I and II), since methane was documented as the most abundant hydrocarbon released into the GOM sites during the spill [15]. Generally, the methanotrophs are bacterial groups capable of both aerobic and anaerobic methane oxidation and belong mainly to either the $\alpha$-Proteobacteria (type II methanotrophs) or the $\gamma$-Proteobacteria (type I methanotrophs) as well as some acidophilic members of the Verrucomicrobiae $[17,18]$. However, several other recent studies have also documented widespread anaerobic methane oxidation among diverse groups and consortia of marine microbial populations [18-22]. In this study, Terrebonne Bay in southern Louisiana was selected as the study site, based on the extent of the Deepwater Horizon oil spill at this particular milieu, combined with several past ecological antecedents and the direct connection of this coastal region to the Mississippi River [23].

*Corresponding author: Ola A Olapade, Department of Biology and the Center for Sustainability and the Environment, Albion College, 611 East Porter Street, Albion, MI 49224, USA; Tel: 517-629-0296; Fax: 517-629-0264; E-mail oolapade@albion.edu

Received May 01, 2013; Accepted June 20, 2013; Published June 27, 2013

Citation: Olapade OA (2013) Molecular Characterization of Bacterial Phylogenetic and Functional Groups at Terrebonne Bay along the Coastline of the Gulf of Mexico. J Pet Environ Biotechnol 4: 144. doi:10.4172/2157-7463.1000144

Copyright: (c) 2013 Olapade OA. This is an open-access article distributed under the terms of the Creative Commons Attribution License, which permits unrestricted use, distribution, and reproduction in any medium, provided the original author and source are credited. 
Citation: Olapade OA (2013) Molecular Characterization of Bacterial Phylogenetic and Functional Groups at Terrebonne Bay along the Coastline of the Gulf of Mexico. J Pet Environ Biotechnol 4: 144. doi:10.4172/2157-7463.1000144

\section{Materials and Methods}

\section{Description of study sites and sample collection}

Water and sediment samples were collected in triplicates at three separate locations along the coastline of the Gulf of Mexico on July $19^{\text {th }}, 2011$, specifically at Terrebonne Bay $\left(29.14134^{\circ},-90.56258^{\circ}\right)$ in southern Louisiana (USA) as previously described [7]. Subsamples were later removed from each sample and preserved in $8 \%(\mathrm{w} / \mathrm{v})$ paraformaldehyde and $1 \mathrm{X}$ phosphate-buffered saline solution for nucleic acid (4', 6'-diamidino-2-phenylindole \{DAPI $\}$ staining and FISH analyses. During sampling, various water characteristics including temperature, $\mathrm{pH}$, conductivity, oxidation-reduction potential were measured using the YSI model 556 MPS multi-probe system (YSI Incorporated, USA).

\section{DNA extraction, PCR and clone sequencing}

Approximately $500 \mathrm{~mL}$ of water samples were filtered through sterile, $47 \mathrm{~mm}, 0.2 \mathrm{um}$ pore-size filters before storing at $-80^{\circ} \mathrm{C}$ until processed. Total DNA was later extracted from the preserved filters using FastDNA SPIN Extraction kit (MP Biomedicals, Solon, $\mathrm{OH}$, USA) and eluted in $50 \mathrm{uL}$ of sterile deionized water. PCR amplification was then carried out on the extracted and pooled DNA from the replicate samples by targeting the almost full-length 16S rRNA gene with the universal bacterial primer pair 8F (5' AGA GTT GTA TCC TGG CTC AG 3') and 1492R (5'GGT TAC CTT GTT ACG ACT T3') as previously described [7]. The amplified PCR products were then confirmed on agarose gel and purified with a QIAquick PCR purification kit (QIAGEN, Valencia, CA) before subsequently utilized for cloning and sequencing. Clone libraries were constructed using the TOPO TA cloning kit (Invitrogen, Carslbad, CA). Colony PCR was used in screening transformed cells with vector-specific primers [24] and size of products verified by agarose gel electrophoresis.

\section{Phylogenetic and diversity analysis}

A total of 83 clones were successfully sequenced and analyzed using the Sequencher program (version 4.5; Gene Codes Co., Ann Arbor, MI). They were then compared with previously published GenBank sequences using the BLAST system [25] in order to determine their close relatives. Alignment and other manual editing were carried out with ClustalW [26]. The clones were then classified into 66 Operational Taxonomic Units (OTUs) using sequence identity values ranging from $\geq 98 \%$ to $100 \%$. The OTUs were analyzed for species richness, Shannon Index, Simpson's (Reciprocal) Index of diversity, species evenness and Chao-1 richness indicator [27-29]. Rarefaction analysis was also performed to determine the diversity of the clone libraries using the freeware program Analystical Rarefaction version 1.3 (S. M. Holland: www.uga.edu/strata/software/Software.html).

\section{Bacterial enumeration}

Direct Counts (DAPI Staining): Total bacterial numbers in the preserved samples were determined by concentrating onto $0.2 \mu \mathrm{m}$ poresize black polycarbonate filters (Poretics, Livermore, CA) and staining with DAPI solution for 5 minutes. Filters were rinsed with sterile water and then mounted onto glass slides with Type FF immersion oil [30]. Bacterial cells in 10 separate fields were then counted using an epifluorescence microscope.

Fluorescence In Situ Hybridization: FISH analyses were used to determine the abundance of different bacterial phylogenetic groups as described in Lomans et al. [31] and Mills et al. [32]. Briefly, bacterial cells in the preserved water samples were concentrated onto $0.2 \mu \mathrm{m}$ pore-size anodisc or polycarbonate filters (Whatman, Maidstone, UK), and then rinsed with deionized water, treated with $1 \mathrm{~mL} 0.1 \%$ Nonidet P-40 (Sigma Aldrich, St. Louis, MO). $40 \mu \mathrm{L}$ of Texas red-labeled probe (Sigma Genosys, The Woodlands, TX; [5 ng/ $\mu \mathrm{L}$ final concentration]) dissolved in hybridization buffer (6X standard saline citrate $\{\mathrm{SSC}\}$, $0.02 \mathrm{M}$ TRIZMA base at pH7.0, $0.1 \%$ sodium dodecyl sulfate $\{$ SDS\}, $0.01 \%$ polyadenylic acid, and $30 \%$ formamide) were then added to the filters before incubating for $4 \mathrm{~h}$ at the appropriate temperature (Table 1). After the incubation, filters were washed twice with $400 \mu \mathrm{L}$ of wash buffer (0.9 M NaCl, 0.02 M Tris-pH7, 0.1\% SDS) and incubated with $80 \mu \mathrm{L}$ of wash buffer for 10 minutes at the hybridization temperature. The filters were then rinsed twice with $400 \mu \mathrm{L}$ sterile deionized water before they were mounted on glass slides with immersion oil. Cells that hybridized to each probe were enumerated using the epifluorescence microscopy by counting at least 300 fields on triplicate slides.

\section{Nucleotide sequence accession numbers}

Nucleotide gene sequences obtained were already submitted to $\mathrm{DDBJ} / \mathrm{GenBank} / \mathrm{EMBL}$ under accession numbers AB691143 to AB691225.

\section{Results}

\section{Environmental variables at study site}

Mean values for the various water characteristics that were measured in triplicates at the study sites are: temperature $\left(30.74^{\circ} \mathrm{C}\right)$, $\mathrm{pH}(7.85)$, dissolved oxygen $(109.8 \%)$, conductivity $(14.27 \mathrm{mS} / \mathrm{cm})$ and oxidation-reduction potential $(10.87 \mathrm{mV})$.

\section{Clone library composition and community diversity assessment}

Analysis of the $8316 \mathrm{~S}$ ribosomal RNA gene sequences revealed eight distinct phylogenetic groups, including bacterial members belonging to the Cyanobacteria, four subclasses (i.e. $\alpha-, \beta-, \gamma-\delta$-) of the Proteobacteria, Bacteroidetes, Actinobacteria, and the Firmicutes (Figure 1). Overall, members of the Cyanobacteria, accounted for the highest clone representation with $28 \%$, followed by the $\beta$ Proteobacteria (20.5\%), Bacteroidetes (17\%) and Actinobacteria (12\%). The percent representations by the different OTUs detected within the clone library constructed after comparing to their closest relatives in the NCBI database are presented in Table 2.

\begin{tabular}{|c|c|c|c|c|}
\hline Probe & Taxa & Sequence (5'-3') & Hybridizing Temp $\left({ }^{\circ} \mathrm{C}\right)$ & Reference \\
\hline EUB338 & Domain Bacteria & GCTGCCTCCCGTAGGAGT & 48 & Amann et al. [46] \\
\hline ALF1b & $\alpha$-proteobacteria & CGTTCG (C/T)TCTGAGCCAG & 54 & Amann et al. [47] \\
\hline GAM42a & y-proteobacteria & GCCTTCCCACATCGTTT & 57 & Manz et al. [48] \\
\hline SRB385 & Sulfate-Reducing-Bacteria & CGGCGTCGCTGCGTCAGG & 53 & Amann et al. [46] \\
\hline$\beta-A 0233$ & Ammonia-oxidizing-Bacteria & AGCTAATCAGRCATCGG & 44 & Stephen et al. [49] \\
\hline$M-450$ & Type I Methanotrophs & ATCCAGGTACCGTCATTATC & 46 & Eller et al. [4] \\
\hline M-84 & Type II Methanotrophs & CCACTCGTCAGCGCCCGA & 46 & Eller et al. [4] \\
\hline
\end{tabular}

Table 1: Oligonucleotide sequences, target and hybridization conditions for probes used in this study. 


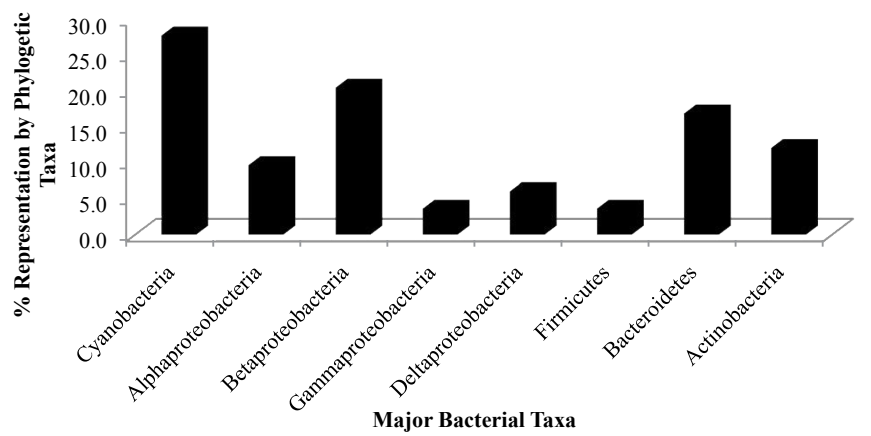

Figure 1: Percent distribution of major bacterial phylogenetic groups based on 16S rRNA gene sequences from the coastal bacterioplankton assemblages in Terrebonne Bay along the Gulf of Mexico.

Among the Proteobacteria, members of the $\beta$-Proteobacteria subclass dominated especially including several hydrocarbon-utilizing bacterial species as Methylibium petroleiphilum, Burkholderia cepacia and Methylophilus methylotrophus. Conversely, bacterial members of the a-Proteobacterial subclass accounted for only $9.6 \%$ of the total clone library composition including species of Oceanicola pacificus and Shinella zoogloeoides belonging to the pyrene and pyridine-degrading consortia. Clones belonging to the $\gamma$ - and $\delta$-Proteobacteria accounted for only $3.6 \%$ and $6.0 \%$ of total populations, respectively, including species such as Hydrocarboniphaga effuse and Desulfofaba fastidiosa.

Results from the various diversity measures analyzed revealed high bacterial diversity within the bacterioplankton assemblage at the bay site examined. Specifically, the Simpson's (Reciprocal) index of diversity was 46.2 , while the species evenness was 0.969 . Equally high were the numbers calculated to be 217.3 and 4.06 for the Chao 1 estimate of species richness and the Shannon Weiner Index, respectively. Rarefaction analysis revealed that the amounts of clones sequenced and screened are probably not sufficient for the estimation of the bacterial diversity within the clone libraries (Figure 2).

\section{Abundances of bacterial phylogenetic and functional groups}

Numbers of total bacteria within the bacterioplankton and benthic assemblages averaged about $3.5 \times 10^{7} / \mathrm{mL}$ and $1.5 \times 10^{8} / \mathrm{g}$, respectively. While, Domain Bacteria occurrence accounted for between $11 \%$ and $20 \%$ of total bacterial counts in the water and sediment at average abundance of $4.0 \times 10^{6} / \mathrm{mL}$ and $3.0 \times 10^{7} / \mathrm{g}$ respectively (Figure $3 \mathrm{a}$ and $3 \mathrm{~b}$ ). When two subclasses (i.e. $\mathrm{a}-$, and $\gamma^{-}$) of the Proteobacteria were enumerated, their numbers were comparable between both the bacterioplankton and benthic assemblages, although members of $\alpha$ Proteobacteria were found to be numerically more dominant within both habitats at the bay site (Figure $4 \mathrm{a}$ and $4 \mathrm{~b}$ ).

The occurrences of both type 1 and II methanotrophic functional bacterial populations followed the same trend and on average were at least one order of magnitude higher within the sediment than in the bacterioplankton communities (Figure $4 \mathrm{a}$ and $4 \mathrm{~b}$ ). Comparatively, the type 1 group were more numerically dominant than the type II, in both water and sediment samples examined. In contrast, the abundances of the other two functional groups examined i.e., the sulfate-reducing and the ammonia-oxidizing bacterial populations differed in their pattern of occurrences within both the bacterioplankton and benthic assemblages. Specifically, numbers of AO233-hybridized cells were found to be higher than those detected with the SRB385 probe in the sediment; conversely, the entire opposite in occurrence was the case for both populations enumerated in the water samples (Figure $4 \mathrm{a}$ and $4 \mathrm{~b}$ ).

\section{Discussion}

In this study, by applying combinations of several cultureindependent (i.e. nucleic acid staining, fluorescence in situ hybridization

\begin{tabular}{|c|c|c|c|}
\hline & Closest Phylogenetic Taxa & GenBank Acc. & Abundance \\
\hline & from NCBI & Number & $(n / \%) a$ \\
\hline A & Cyanobacteria & & \\
\hline 1 & Uncultured Cyanobacterium & HQ242211 & $1 / 1.20$ \\
\hline 2 & Uncultured Cyanobacterium & JF966676 & $1 / 1.20$ \\
\hline 3 & Uncultured Cyanobacterium & EU930687 & $1 / 1.20$ \\
\hline 4 & Uncultured Cyanobacterium & AM690936 & $6 / 7.23$ \\
\hline 5 & Uncultured Cyanobacterium & AB491631 & $2 / 2.41$ \\
\hline 6 & Uncultured Cyanobacterium & FJ352328 & $1 / 1.20$ \\
\hline 7 & Uncultured Cyanobacterium & GQ349130 & $1 / 1.20$ \\
\hline 8 & Uncultured Cyanobacterium & FM995186 & $1 / 1.20$ \\
\hline 9 & Uncultured Cyanobacterium & KC545747 & $1 / 1.20$ \\
\hline 10 & Uncultured Cyanobacterium & FJ763779 & $1 / 1.20$ \\
\hline 11 & Uncultured Cyanobacterium & EU780238 & $1 / 1.20$ \\
\hline 12 & Uncultured Cyanobacterium & JF966674 & $1 / 1.20$ \\
\hline 13 & Uncultured Cyanobacterium & EU800916 & $1 / 1.20$ \\
\hline 14 & Uncultured Cyanobacterium & HM057705 & $1 / 1.20$ \\
\hline 15 & Uncultured Cyanobacterium & AM259752 & $1 / 1.20$ \\
\hline 16 & Uncultured Cyanobacterium & HQ914635 & $1 / 1.20$ \\
\hline 17 & Uncultured Cyanobacterium & GU074287 & $1 / 1.20$ \\
\hline B & Alphaproteobacteria & & \\
\hline 18 & Rhodobacter veldkampii & NR043405 & $1 / 1.20$ \\
\hline 19 & Shinella zoogloeoides & NR041341 & $1 / 1.20$ \\
\hline 20 & Shinella zoogloeoides & NR041342 & $1 / 1.20$ \\
\hline 21 & Rhodoplanes serenus & NR040936 & $1 / 1.20$ \\
\hline 22 & Anderseniella baltica & NR042626 & $2 / 2.41$ \\
\hline 23 & Skermanella aerolata & NR043929 & $1 / 1.20$ \\
\hline 24 & Oceanicola pacificus & NR043915 & $1 / 1.20$ \\
\hline C & Betaproteobacteria & & \\
\hline 25 & Methylibium petroleiphilum & NR041768 & $1 / 1.20$ \\
\hline 26 & Burkholderia ginsengisoli & NR041288 & $1 / 1.20$ \\
\hline 27 & Massilia lutea & NR043310 & $2 / 2.41$ \\
\hline 28 & Burkholderia cepacia & NR041719 & $1 / 1.20$ \\
\hline 29 & Methylophilus methylotrophus & NR041257 & $1 / 1.20$ \\
\hline 30 & Denitratisoma oestradiolicum & NR043249 & $2 / 2.41$ \\
\hline 31 & Burkholderia endofungorum & NR042584 & $1 / 1.20$ \\
\hline 32 & Massilia dura & NR043307 & $1 / 1.20$ \\
\hline 33 & Methylobacillus flagellatus & NR043691 & $1 / 1.20$ \\
\hline 34 & Hydrogenophaga pseudoflava & NR028717 & $1 / 1.20$ \\
\hline 35 & Azoarcus buckelii & NR027190 & $1 / 1.20$ \\
\hline 36 & Methylobacillus flagellatus & NR043691 & $1 / 1.20$ \\
\hline 37 & Hydrogenophaga taeniospiralis & NR028716 & $1 / 1.20$ \\
\hline 38 & Burkholderia cepacia & NR041719 & $1 / 1.20$ \\
\hline 39 & Methylobacillus flagellatus & NR043691 & $1 / 1.20$ \\
\hline D & Gammaproteobacteria & & \\
\hline 40 & Thioalkalivibrio denitrificans & NR028745 & $1 / 1.20$ \\
\hline 41 & Singularimonas varicoloris & NR042175 & $1 / 1.20$ \\
\hline 42 & Hydrocarboniphaga effusa & NR029102 & $1 / 1.20$ \\
\hline$E$ & Deltaproteobacteria & & \\
\hline 43 & Desulfofaba fastidiosa & NR025746 & $1 / 1.20$ \\
\hline 44 & Desulfuromusa bakii & NR026175 & $1 / 1.20$ \\
\hline 45 & Geobacter thiogenes & NR028775 & $1 / 1.20$ \\
\hline 46 & Desulfuromonas alkaliphilus & NR043709 & $1 / 1.20$ \\
\hline 47 & Desulfuromusa bakii & NR026175 & $1 / 1.20$ \\
\hline
\end{tabular}


Citation: Olapade OA (2013) Molecular Characterization of Bacterial Phylogenetic and Functional Groups at Terrebonne Bay along the Coastline of the Gulf of Mexico. J Pet Environ Biotechnol 4: 144. doi:10.4172/2157-7463.1000144

\begin{tabular}{|c|c|c|c|}
\hline $\mathbf{F}$ & Firmicutes & & \\
\hline $\mathbf{4 8}$ & Anaeroarcus burkinensis & NR025298 & $1 / 1.20$ \\
\hline $\mathbf{4 9}$ & Parasporobacterium paucivorans & NR025390 & $1 / 1.20$ \\
\hline $\mathbf{5 0}$ & Thermincola carboxydiphila & NR043010 & $1 / 1.20$ \\
\hline $\mathbf{G}$ & Bacteroidetes & & \\
\hline $\mathbf{5 1}$ & Flavisolibacter ginsengisoli & NR041500 & $2 / 2.41$ \\
\hline $\mathbf{5 2}$ & Owenweeksia hongkongensis & NR040990 & $5 / 6.02$ \\
\hline $\mathbf{5 3}$ & Flavobacterium sp & NR040990 & $1 / 1.20$ \\
\hline $\mathbf{5 4}$ & Perexilibacter aurantiacus & NR041534 & $2 / 2.41$ \\
\hline $\mathbf{5 5}$ & Robiginitalea myxolifaciens & NR041514 & $1 / 1.20$ \\
\hline $\mathbf{5 6}$ & Lishizhenia caseinilytica & NR041043 & $1 / 1.20$ \\
\hline $\mathbf{5 7}$ & Fluviicola taffensis & NR041911 & $1 / 1.20$ \\
\hline $\mathbf{5 8}$ & Haliscomenobacter hydrossis & NR042316 & $1 / 1.20$ \\
\hline $\mathbf{H}$ & Actinobacteria & & \\
\hline $\mathbf{5 9}$ & Streptomyces hebeiensis & NR029091 & $1 / 1.20$ \\
\hline $\mathbf{6 0}$ & Ferrimicrobium acidiphilum & NR041768 & $1 / 1.20$ \\
\hline $\mathbf{6 1}$ & Ilumatobacter fluminis & NR041633 & $2 / 2.41$ \\
\hline $\mathbf{6 2}$ & Ferrimicrobium acidiphilum & NR041798 & $2 / 2.41$ \\
\hline $\mathbf{6 3}$ & Streptomyces hebeiensis & NR029091 & $1 / 1.20$ \\
\hline $\mathbf{6 4}$ & Ilumatobacter fluminis & NR041633 & $1 / 1.20$ \\
\hline $\mathbf{6 5}$ & Kitasatospora saccharophila & NR041538 & $1 / 1.20$ \\
\hline $\mathbf{6 6}$ & Patulibacter minatonensis & NR041254 & $1 / 1.20$ \\
\hline & & & \\
\hline $\mathbf{5 0}$ & N3 cones & \\
\hline
\end{tabular}

$\mathrm{a}=$ total of 83 clones

Table 2: Percent occurrences of bacterial phylogenetic groups in the bacterioplankton assemblage at Terrebonne Bay along the Gulf of Mexico.

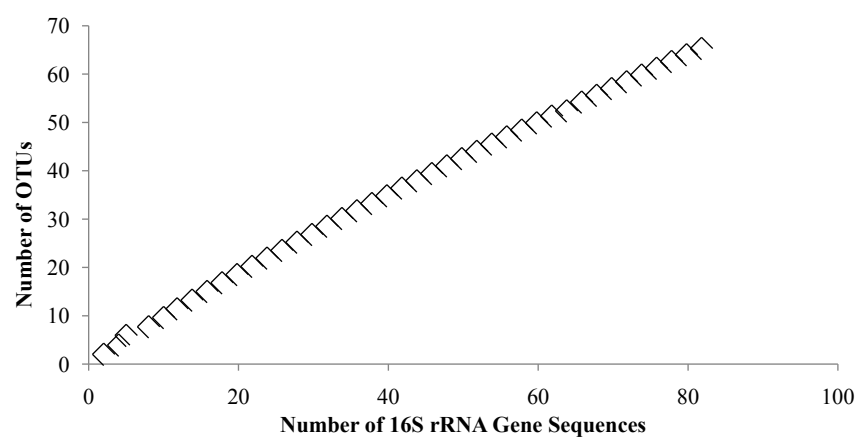

Figure 2: Percent abundance of different OTUs presented by genus from Terrebone Bay along the Gulf of Mexico.

(FISH), gene cloning and sequencing approaches, the impact of the Deepwater Horizon oil spill on indigenous microbial assemblages was assessed qualitatively and quantitatively at the study site in Terrebonne Bay. Sequence diversity analyses revealed the presence of eight distinct bacterial phyla comprising mostly of various hydrocarbon-utilizing phylotypes that strongly suggests that such a shift was stimulated by the oil disaster at the GOM. This result corroborates earlier documentation that also showed strong stimulation of indigenous bacterial populations, especially the $\gamma$-Proteobacteria members closely associated with petroleum degradation at the same polluted GOM sites $[33,15]$. Interestingly, results documented in some earlier studies that were conducted along the same coastlines of the GOM, prior to the oil spillage $[1,32,7]$ appeared to show different compositions of the microbiota compared to those reported in this current study, therefore indicating that a shift in the dominant microbial groups must have occurred. Particularly, Olapade [7] observed majority of sequences (i.e. between $30 \%$ and $60 \%$ of cloned libraries) within the bacterioplankton communities in three GOM sites to be closely related to gene sequences belonging to unknown bacteria. This shift in the major microbial phylogenetic groups probably further validate the suggestion that the phyla with hydrocarbon-degrading abilities were relatively more stimulated and supported by the oil plume at these GOM locations $[14,33,15]$.

Generally, variations of sequences belonging to globally distributed bacterial taxa are typically found within microbial communities in coastal marine environments $[34,2,5]$. However, in this study the relatively high occurrence of $\beta$-Proteobacteria found is quite suggestive of the oil plume influence, especially given the relatively rare occurrence of this particular taxa in marine milieus as compared to freshwater environments $[28,7,8]$. Moreover, the bacterial members identified as belonging to the $\beta$-Proteobacteria subclass within the clone library were mostly hydrocarbon (e.g., methanol) degraders, including Methylibium petroleiphilum, Burkholderia cepacia, Hydrogenophaga taeniospiralis and Methylobacillus flagellates species [35-37].

Furthermore, bacterial members of the $\delta$ - Proteobacteria and the Firmicutes that represented about $6 \%$ and $3 \%$ of total clone populations comprised of several species such as Desulfofaba fastidiosa, Desulfuromusa bakii and Parasporobacterium paucivorans which are capable of utilizing various crude-oil derived compounds including methyloxylated aromatics, propionate and sulfur [38-40]. Typically, majority of bacterial species belonging to these two taxa are reportedly associated with soil and sediment in coastal marine environments especially during tidal events $[1,7]$. Therefore, the presence of high numbers of hydrocarbon-utilizing bacterial phyllotypes in this study within the bacterioplankton communities strongly suggest a possible change in the physiological and metabolic profiles of some of the taxa in response to the available hydrocarbon substrates.

The relatively high representations by the $\alpha$-Proteobacteria (10\%) and the Bacteroidetes (17\%) were not at all surprising and further
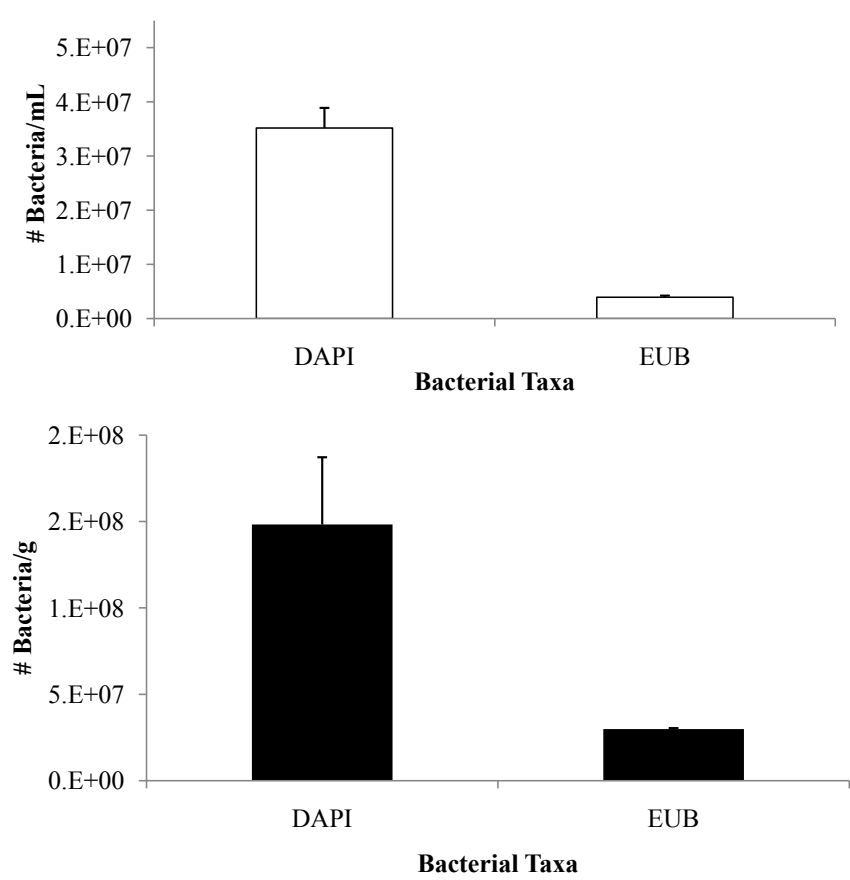

Figure 3: Numbers of total bacteria (as determined by DAPI staining) and domain bacteria (determined by FISH) in the coastal bacterioplankton [A] and benthos $[B]$ assemblages in Terrebonne Bay along the Gulf of Mexico. Values represent mean \pm 1 SE $(n=3)$. 


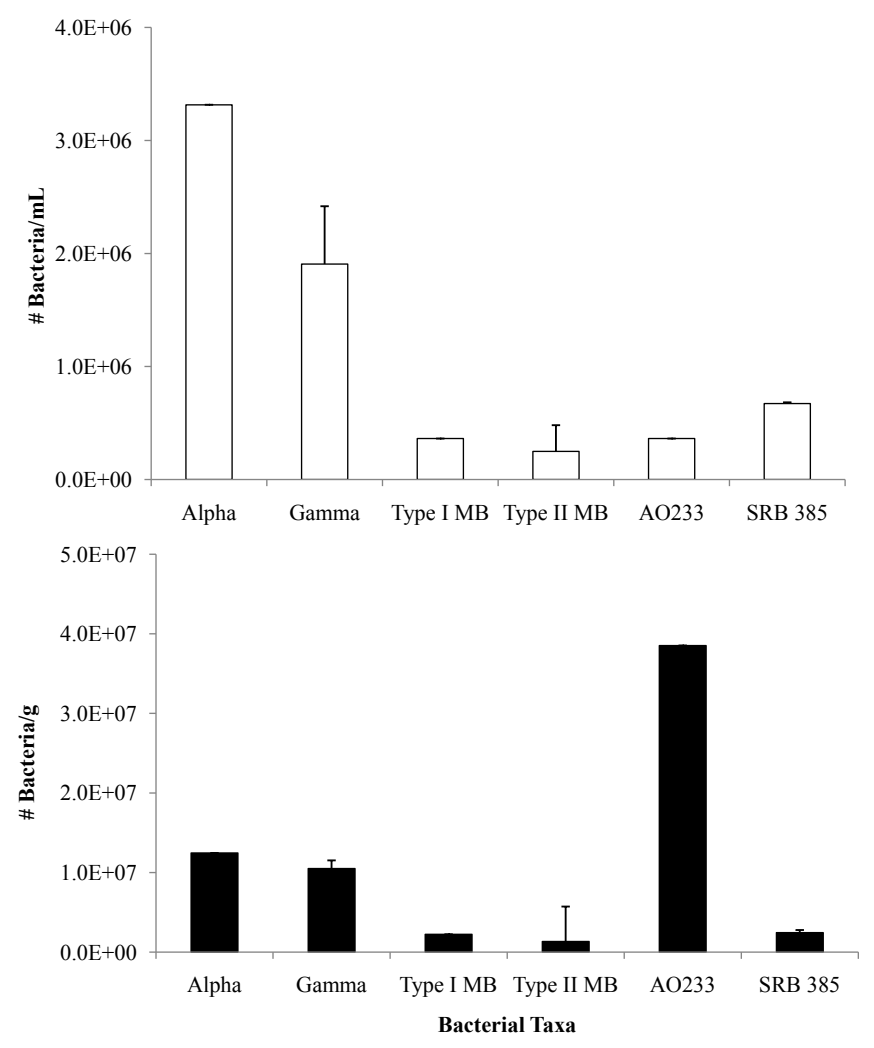

Figure 4: Numbers of $\alpha$ - and $\gamma$ - Proteobacteria; Type I and Type II methanotrophs and Ammonia-oxidizing and sulfate-reducing bacterial populations (determined by $\mathrm{FISH}$ ) in the coastal bacterioplankton $[\mathrm{A}]$ and benthos $[B]$ assemblages in Terrebonne Bay along the Gulf of Mexico. Values represent mean \pm 1 SE $(n=3)$.

corroborate earlier documentations of the dominance of the two bacterial taxa in coastal marine systems [5]. Species such as Shinella zoogloeoides that are capable of pyridine degradation [41] dominated a-Proteobacteria clones, while members of the Bacteroidetes that typically play significant roles in the decomposition of highmolecular-weight organic compounds in marine environments [42], were mostly represented by Owenweeksia hongkongensis, within the bacterioplankton communities.

The numerical dominance of both types of the methanotrophs examined within the sediment matrixes as compared to populations in the bacterioplankton is further indicative of their typical rapid response towards the source of methane release [43], which in this case was close to the ocean sub-seafloor [28]. The close proximity to methane source may also partly explain the higher presence of bacterial members belonging to the ammonia-oxidizing and sulfate-reducing bacterial populations, despite the frequent methane oxidization in both aerobic and anaerobic environments [22,44]. The disparity observed here regarding the occurrence of the $\mathrm{AOB}$ populations strongly agrees with an earlier similar study from the Northwestern Mediterranean Sea which indicated that members of this functional group might probably occupy distinct environmental niches in marine systems, because of their lower representations in planktonic libraries as compared to those that were particle-associated [45]. Similar contrasting patterns have also been observed especially in the diversity of aerobic methanotrophs between planktonic and sediment- associated assemblages in marine environments [17]. In this study conducted in two seep systems, they reported that while the sediment associated methanotrophs were less diverged and dominated by single taxa, in contrast the diversity within the planktonic community were found to be limited to a small number of moderately diverged clades within the same Methylococcaceae genus.

In conclusion, the results from both FISH and 16S rRNA gene clone sequences clearly reflects the subsequent shift in the bacterial community structure and composition at Terrebonne Bay in southern Louisiana in response to the tragic methane and crude oil discharges from the Deepwater Horizon rig along the Gulf of Mexico. This obvious shift in bacterial community diversity to mostly hydrocarbondegrading phylotypes at the GOM site examined, further highlights both the ecological importance as well as various degradative potentials of autochthonous bacterial assemblages within contaminated coastal marine milieus.

\section{Acknowledgements}

The study was supported mostly by the Albion College Hewlett-Mellon Faculty Development Funds. Sincere thanks to Lori Duff, Freyja Davis, Dave Carey and Kurt Hellman for various support during the study period.

\section{References}

1. Chauhan A, Cherrier J, Williams HN (2009) Impact of sideways and bottom-up control factors on bacterial community succession over a tidal cycle. Proc Nat Acad Sci USA 106: 4301-4306.

2. Cottrell MT, Kirchman DL (2000) Community composition of marine bacterioplankton determined by $16 \mathrm{~S}$ rRNA gene clone libraries and fluorescence in situ hybridization. Appl Environ Microbiol 66: 5116-5122.

3. Giovannoni SJ, Rappé M (2000) Evolution, diversity and molecular ecology of marine prokaryotes. In Microbial ecology of the oceans DL Kirchman WileyLiss, New York USA.

4. Eller G, Stubner S, Frenzel P (2001) Group-specific 16S rRNA targeted probes for the detection of type I and type II methanotrophs by fluorescence in situ hybridisation. FEMS Microbiol Lett 198: 91-97.

5. Giovannoni SJ, Stingl U (2005) Molecular diversity and ecology of microbial plankton. Nature 437: 343-348.

6. Hazen TC, Dubinsky EA, DeSantis TZ, Andersen GL, Piceno YM, et al. (2010) Deep-sea oil plume enriches indigenous oil-degrading bacteria. Science 330 204-208.

7. Olapade OA (2010) Molecular analyses of the diversity in marine bacterioplankton assemblages along the coastline of the northeastern Gulf of Mexico. Can J Microbiol 56: 853-863.

8. Rappé MS, Vergin K, Giovannoni SJ (2000) Phylogenetic comparisons of coastal bacterioplankton community with its counterparts in open ocean and freshwater systems. FEMS Microbiol Ecol 33: 219-232.

9. James R Bragg, Roger C Prince, James Harner E, Ronald M Atlas (1994) Effectiveness of bioremediation for the Exxon Valdez oil spill. Nature 368: 413 418

10. Röling WF, Milner MG, Jones DM, Fratepietro F, Swannell RP, et al. (2004) Bacterial community dynamics and hydrocarbon degradation during a fieldscale evaluation of bioremediation on a mudflat beach contaminated with buried oil. Appl Environ Microbiol 70: 2603-2613.

11. Swannell RPJ, Mitchell D, Lethbridge G, Jones D, HeathD, et al. (1999) A Field Demonstration of the Efficacy of Bioremediation to Treat Oiled Shorelines Following the Sea Empress Incident. Environ Technol 20: 863-873.

12. Atlas RM, Bartha R (1972) Degradation and mineralization of petroleum in sea water: limitation by nitrogen and phosphorous. Biotechnol Bioeng 14: 309-318.

13. Olapade OA (2012) Diel fluctuations in the abundance and community diversity of coastal bacterioplankton assemblages over a tidal cycle. Microb Ecol 63 96-102.

14. Valentine DL, Kessler JD, Redmond MC, Mendes SD, Heintz MB, et al. (2010) Propane respiration jump-starts microbial response to a deep oil spill. Science 330: 208-211.

15. Kostka JE, Prakash O, Overholt WA, Green SJ, Freyer G, et al. (2011) 
Citation: Olapade OA (2013) Molecular Characterization of Bacterial Phylogenetic and Functional Groups at Terrebonne Bay along the Coastline of the Gulf of Mexico. J Pet Environ Biotechnol 4: 144. doi:10.4172/2157-7463.1000144

Hydrocarbon-degrading bacteria and the bacterial community response in gulf of Mexico beach sands impacted by the deepwater horizon oil spill. Appl Environ Microbiol 77: 7962-7974.

16. Holmes AJ, Roslev P, McDonald IR, Iversen N, Henriksen K, et al. (1999) Characterization of methanotrophic bacterial populations in soils showing atmospheric methane uptake. Appl Environ Microbiol 65: 3312-3318.

17. Tavormina PL, Ussler W 3rd, Orphan VJ (2008) Planktonic and sedimentassociated aerobic methanotrophs in two seep systems along the North American margin. Appl Environ Microbiol 74: 3985-3995.

18. Boetius A, Ravenschlag K, Schubert CJ, Rickert D, Widdel F, et al. (2000) A marine microbial consortium apparently mediating anaerobic oxidation of methane. Nature 407: 623-626.

19. Dunfield PF, Yuryev A, Senin P, Smirnova AV, Stott MB, et al. (2007) Methane oxidation by an extremely acidophilic bacterium of the phylum Verrucomicrobia. Nature 450: 879-882

20. Ettwig KF, Butler MK, Le Paslier D, Pelletier E, Mangenot S, et al. (2010) Nitrite-driven anaerobic methane oxidation by oxygenic bacteria. Nature 464 : 543-548.

21. Hanson RS, Hanson TE (1996) Methanotrophic bacteria. Microbiol Rev 60 439-471.

22. Milucka J, Ferdelman TG, Polerecky L, Franzke D, Wegener G, et al. (2012) Zero-valent sulphur is a key intermediate in marine methane oxidation. Nature 491: 541-546.

23. Penland S, Sutter JR, and McBride RA (1987) Delta plain development and sea level history in Terrebone coastal region, Lousiana. In: Kraus NC Coasta Sediments 87. American Society of Civil Engineers, NewYork 1689-1704.

24. Messing J (1983) New M13 vectors for cloning. Methods Enzymol 101: 20-78.

25. Altschul SF, Madden TL, Schaffer AA, Zhang J, Zhang Z, et al. (1997) Gapped BLAST and PSI-BLAST: a new generation of protein database search programs. Nucleic Acids Res 25: 3389-3402.

26. Perrière G, Gouy M (1996) WWW-query: an on-line retrieval system for biological sequence banks. Biochimie 78: 364-369.

27. Chao A (1984) Nonparametric Estimation of the Number of Classess in a Population. Scand J Statist 11: 265-270.

28. Chao A (1987) Estimating the population size for capture-recapture data with unequal catchability. Biometrics 43: 783-791.

29. Schloss PD, Handelsman J (2006) Introducing SONS, a tool for operationa taxonomic unit-based comparisons of microbial community memberships and structures. Appl Environ Microbiol 72: 6773-6779.

30. Porter KG, Feig YS (1980) The Use of DAPI for Identifying and Counting Aquatic Microflora. Limnol Oceanogr 25: 943-948.

31. Lomans BP, Leijdekkers P, Wesselink JJ, Bakkes P, Pol A (2001) Obligate sulfide-dependent degradation of methoxylated aromatic compounds and formation of methanethiol and dimethyl sulfide by a freshwater sediment isolate, Parasporobacterium paucivorans gen. nov., sp. nov. Appl Environ Microbiol 67: 4017-4023.

32. Mills HJ, Hunter E, Humphrys M, Kerkhof L, McGuinness L, et al. (2008) Characterization of nitrifying, denitrifying, and overall bacterial communities in permeable marine sediments of the northeastern Gulf of Mexico. Appl Environ Microbiol 74: 4440-4453.

33. Kessler JD, Valentine DL, Redmond MC, Du M, Chan EW, et al. (2011) A persistent oxygen anomaly reveals the fate of spilled methane in the deep Gulf of Mexico. Science 331: 312-315.

34. Britschgi TB, Giovannoni SJ (1991) Phylogenetic analysis of a natural marine bacterioplankton population by rRNA gene cloning and sequencing. App Environ Microbiol 57: 1707-1713.

35. Chistoserdova L, Lapidus A, Han C, Goodwin L, Saunders L, et al. (2007) Genome of Methylobacillus flagellatus, molecular basis for obligate methylotrophy, and polyphyletic origin of methylotrophy. J Bacteriol 189: 4020 4027.

36. Lambo AJ, Patel TR (2006) Isolation and characterization of a biphenylutilizing psychrotrophic bacterium, Hydrogenophaga taeniospiralis IA3-A, that cometabolize dichlorobiphenyls and polychlorinated biphenyl congeners in Aroclor 1221. J Basic Microbiol 46: 94-107.

37. Nakatsu CH, Hristova K, Hanada S, Meng XY, Hanson JR, et al. (2006) Methylibium petroleiphilum gen. nov., sp. nov., a novel methyl tert-butyl etherdegrading methylotroph of the Betaproteobacteria. Int J Syst Evol Microbio 56: 983-989.

38. Abildgaard L, Ramsing NB, Finster K (2004) Characterization of the marine propionate-degrading, sulfate-reducing bacterium Desulfofaba fastidiosa $\mathrm{sp}$. nov. and reclassification of Desulfomusa hansenii as Desulfofaba hansenii comb. nov. Int J Syst Evol Microbiol 54: 393-399.

39. Werner Liesack, Kai Finster (1994) Phylogenetic Analysis of Five Strains of Gram-Negative, Obligately Anaerobic, Sulfur-Reducing Bacteria and Description of Desulfirornusa gen. nov., Including Desulfuromusa kysingii sp. nov., Desulfurornusa bakii sp. nov., and Desulfuromusa succinoxidans sp. nov. Int J Syst Bacteriol 44: 753-758

40. González JM, Moran MA (1997) Numerical dominance of a group of marine bacteria in the alpha-subclass of the class Proteobacteria in coastal seawater. Appl Environ Microbiol 63: 4237-4242.

41. Bai $Y$, Sun $Q$, Zhao C, Wen D, Tang X (2009) Aerobic degradation of pyridine by a new bacterial strain, Shinella zoogloeoides BC026. J Ind Microbio Biotechnol 36: 1391-1400.

42. Cottrell MT, Kirchman DL (2000) Natural assemblages of marine proteobacteria and members of the Cytophaga-Flavobacter cluster consuming low- and highmolecular-weight dissolved organic matter. Appl Environ Microbiol 66: 1692 1697.

43. Ronald S Oremland, Charles W Culbertson (1992) Importance of methaneoxidizing bacteria in the methane budget as revealed by the use of a specific inhibitor. Nature 356 421-423.

44. McDonald IR, Bodrossy L, Chen Y, Murrell JC (2008) Molecular ecology techniques for the study of aerobic methanotrophs. Appl Environ Microbiol 74 1305-1315.

45. Phillips CJ, Smith Z, Embley TM, Prosser JI (1999) Phylogenetic differences between particle-associated and planktonic ammonia-oxidizing bacteria of the beta subdivision of the class Proteobacteria in the Northwestern Mediterranean Sea. Appl Environ Microbiol 65: 779-786.

46. Amann RI, Krumholz L, Stahl DA (1990) Fluorescent-oligonucleotide probing of whole cells for determinative, phylogenetic, and environmental studies in microbiology. J Bacteriol 172: 762-770.

47. Amann RI, Ludwig W, Schleifer KH (1995) Phylogenetic identification and in situ detection of individual microbial cells without cultivation. Microbiol Rev 59: 143-169.

48. Manz W, Amann R, Ludwig W, Wagner M, Schleifer KH (1992) Phylogenetic Oligodeoxynucleotide Probes for the Major Subclasses of Proteobacteria: Problems and Solutions. Syst Appl Microbiol 15: 593-600.

49. Stephen JR, Kowalchuk GA, Bruns MAV, McCaig AE, Phillips CJ, et al. (1998) Analysis of ubroup Proteobacterial Ammonia Oxidizer populations in soil by denaturing gradient gel electrophoresis analysis and hierarchical phylogenetic probing. Appl Environ Microb 64: 2958-2965 